\title{
Effects of Microbial Growth Conditions on Synthesis of Magnetite Nanoparticles using Indigenous Fe(III)-Reducing Bacteria
}

\author{
Yumi Kim and Yul Roh * \\ Department of Earth and Environmental Sciences, Chonnam National University, Gwangju 61186, Korea; \\ yumikim@jnu.ac.kr \\ * Correspondence: rohy@jnu.ac.kr; Tel.: +82-62-530-3458
}

Received: 2 March 2018; Accepted: 11 May 2018; Published: 14 May 2018

\begin{abstract}
Recent researches have shown that microbe-metal interactions play an important role in metal cycling and biomineralization in subsurface environments. The objective of this research was to study the effects of microbial growth conditions for size control on the synthesis of magnetite nanoparticles using Fe(III)-reducing bacteria enriched from intertidal flat sediments in Korea. The microbial formation of the magnetite nanoparticles was examined under various incubation temperatures $\left(8-35^{\circ} \mathrm{C}\right)$, concentrations $(20-60 \mathrm{mM})$ of magnetite precursor, medium $\mathrm{pHs}$ (6.5-8.5), and incubation times (0-3 weeks). The Fe(III)-reducing bacteria formed 2 10 nm-sized magnetite $\left(\mathrm{Fe}_{3} \mathrm{O}_{4}\right)$ by reduction of $40 \mathrm{mM}$ akaganeite, especially under the conditions at $25^{\circ} \mathrm{C}$ and medium $\mathrm{pH}=8.5$ within a 1-week incubation time. The magnetite nanoparticles formed by microbial processes exhibited superparamagnetic behavior.
\end{abstract}

Keywords: magnetite; nanoparticle; biomineralization; Fe(III)-reducing bacteria; Clostridium species

\section{Introduction}

The synthesis of nano-sized minerals using microorganisms would receive an advantage from the development of clean, nontoxic, and environmentally acceptable chemistry procedures [1-4]. However, this method is still in its development stage which is attributed to difficulties in controlling the size and physical properties of the particles. Gericke and Pinches $(2006 a, b)$ demonstrated that the rate of intracellular particle formation and the morphological character of the nanoparticles were possibly manipulated by controlling growth parameters such as temperature, $\mathrm{pH}$, substrate concentration, and exposure time to substrate [5,6]. Efforts have also been made to manipulate the size and shape of nanoparticles produced extracellularly through alteration of microbial growth parameters. Magnetite $\left(\mathrm{Fe}_{3} \mathrm{O}_{4}\right)$ nanoparticles could possibly be used in diverse applications such as magnetic resonance imaging (MRI) contrast enhancement, magnetic ink, frequency response, and ferrofluid, among other applications [7-11]. In previous studies, a thermophilic fermentative bacterial strain, TOR-39, formed magnetite nanoparticles showing size and morphological changes as a result of crystallographic growth of magnetite during microbial Fe(III)-reduction [12]. The strain PV-4, Shewanella sp., isolated from iron-rich microbial mats at a hydrothermal vent, formed magnetite in a wide range of temperatures from 0 to $37^{\circ} \mathrm{C}$, with the optimum rate at $18^{\circ} \mathrm{C}$ through microbial Fe(III)-reduction [13]. These studies revealed a potential for the synthesis of monodisperse magnetite nanoparticles using bacteria through the alteration of microbial growth conditions.

The objectives of this study were to examine the effects of microbial growth conditions on the synthesis of magnetite nanoparticles and to find out the optimal parameters to achieve control of size and shape of the magnetite nanoparticles by use of indigenous Fe(III)-reducing bacteria enriched from intertidal flat sediments. 


\section{Materials and Methods}

\subsection{Source of Microorganisms and Characterization}

Haejae-2 used in this study is a name of enrichment culture which is subcultured from Haejae-1. $\mathrm{Fe}(\mathrm{III})$-reducing bacteria, Haejae-1, were enriched from the intertidal flat sediments of Haejae in the Muan-gun, Jeonnam province of South Korea. To obtain the anaerobic Fe(III)-reducing bacteria, the intertidal flat sediments were sampled from the shallow subsurface environments ( $5 \sim 10 \mathrm{~cm}$ deep) and stored in a $1 \mathrm{~L}$ glass bottle at $25^{\circ} \mathrm{C}$. Haejae- 1 is a facultative bacterium which grows well at room temperature $\left(25^{\circ} \mathrm{C}\right)$ [14]. In previous studies, Haejae-1 consisting of Clostridium sp., Enterococcus sp. and Serratia sp. reduced $\mathrm{Fe}(\mathrm{III}), \mathrm{Cr}(\mathrm{VI}), \mathrm{Mn}(\mathrm{IV})$, and $\mathrm{As}(\mathrm{V})$ via glucose fermentation [13,14]. In addition, Haejae-2, which is the subculture of Haejae-1, formed nano-sized magnetite coated with organic materials that had a functional group such as carboxyl (-COO-) by the microbial Fe(III)-reducing process [15]. In this study, Haejae-2 was characterized using PCR-DGGE and 16S rRNA gene sequence analysis for microbial diversity. The 16S rRNA gene sequences of related taxa were obtained from the GenBank database [16]. The 16S rRNA gene sequencing and the phylogenetic tree constructing were performed by Environmental Microbiology and Genomics Lab in Chungbuk National University (Cheongju, Korea), and the methods were described in detail in the previous study [16]. High resolution transmission electron microscopy (HR-TEM, Phillips, Amsterdam, The Netherlands) and scanning electron microscopy (SEM, JEOL, Tokyo, Japan) with energy dispersive X-ray (EDS, Phillips) analyses were used to observe the morphology and size of the bacteria.

\subsection{Growth Media Preparation}

The medium for the Haejae-2 growth and magnetite synthesis contained the following ingredients (g/L) [15,17]: $2.5 \mathrm{NaHCO}_{3}, 0.08 \mathrm{CaCl}_{2} \cdot 2 \mathrm{H}_{2} \mathrm{O}, 1.0 \mathrm{NH}_{4} \mathrm{Cl}, 0.2 \mathrm{MgCl}_{2} \cdot 6 \mathrm{H}_{2} \mathrm{O}, 10 \mathrm{NaCl}, 0.5$ yeast extract, 7.2 HEPES (hydroxyl-ethylpiperazine- $N^{\prime}$-2-ethanesulfonic acid), $10 \mathrm{ml}$ trace mineral, and $1 \mathrm{~mL}$ vitamin. The ingredients of trace element solutions and vitamin solutions were described in detail in previous studies $[15,17]$. The dissolved oxygen in the medium was removed by boiling, purging with $\mathrm{N}_{2}$ gas, and dispensing into $125 \mathrm{~mL}$ serum bottles. The bottles were sealed with butyl rubber stoppers and aluminum caps and then autoclaved at $121^{\circ} \mathrm{C}$ and $1.2 \mathrm{kgf} / \mathrm{cm}^{2}$ for $20 \mathrm{~min}$. The medium $\mathrm{pH}$ was about 8.0.

\subsection{Preparation of Magnetite Precursor}

Akaganeite $(\beta-\mathrm{FeOOH})$, which is a poorly crystalline $\mathrm{Fe}(\mathrm{III})$ oxide, was used as a precursor for the synthesis of magnetite nanoparticles. Akaganeite $(\beta-\mathrm{FeOOH})$ was prepared using the following procedure [18]: $10 \mathrm{M} \mathrm{NaOH}$ solution was slowly added into $0.4 \mathrm{M} \mathrm{FeCl}_{3} \cdot 6 \mathrm{H}_{2} \mathrm{O}$ solution to precipitate akaganeite $(\beta-\mathrm{FeOOH})$ by gravity only with rapid stirring at $\mathrm{pH}$. The suspension was then aerated overnight by magnetic stirring for homogeneous oxidation. The akaganeite $(\beta-\mathrm{FeOOH})$ suspension was washed with distilled water thrice and aged at room temperature (about $25^{\circ} \mathrm{C}$ ) under an anoxic atmosphere for 3 months.

\subsection{Experimental Conditions}

In the previous studies, Haejae- 1 consortium showed superior Fe(III)-reduction and magnetite synthesis under room temperature, atmospheric pressure, and a neutral environment $[14,15]$. Under similar conditions, Haejae- 2 consortium were incubated in serum bottles containing $100 \mathrm{~mL}$ medium and $10 \mathrm{mM}$ glucose $\left(\mathrm{C}_{6} \mathrm{H}_{12} \mathrm{O}_{6}\right)$ as an electron donor in this study. The previous culture conditions (e.g., $40 \mathrm{mM}$ electron acceptor, $10 \mathrm{mM}$ electron donor, $25^{\circ} \mathrm{C}$, $\mathrm{pH}$ 7.5, 2-week incubation period) were set as control variables and the manipulated variables were changed by the concentrations of electron acceptor, temperatures, $\mathrm{pHs}$, and periods as independent variables respectively.

To understand the effect of incubation temperature, the bacteria were incubated with $40 \mathrm{mM}$ akaganeite and $10 \mathrm{mM}$ glucose at different temperatures of 8,25 , and $35^{\circ} \mathrm{C}$. To include the effect of iron 
oxyhydroxide concentration as an electron acceptor, the bacteria were exposed to various akaganeite concentrations of 20,40 , and $60 \mathrm{mM}$ in the growth medium with $10 \mathrm{mM}$ glucose at room temperature, respectively. The effects of $\mathrm{pH}$ in the growth medium for magnetite formation were evaluated by inoculating $1 \%(v / v)$ Haejae-2 from a suspended cell culture into different $\mathrm{pHs}$ ranging from 6.5 to 8.5 , with $40 \mathrm{mM}$ akaganeite as an electron acceptor, and $10 \mathrm{mM}$ glucose as an electron donor, respectively. These samples were incubated at room temperature for a two-week period. During the experiments, the suspended nanoparticles were sampled at 24-h, 48-h, 1-week, and 2-week intervals to understand process of magnetite formation using the Fe(III)-reducing bacteria.

\subsection{Mineralogical Characteristics of Biosynthesized Magnetite Nanoparticles}

The mineralogical characteristics of akaganeite used as a magnetite precursor, and microbially synthesized magnetite were examined using X-ray diffraction (XRD) and high resolution transmission electron microscopy (HR-TEM) with energy dispersive X-ray (EDS) analyses.

To collect the biogenic minerals for XRD analysis, the suspension was centrifuged with $3000 \mathrm{rpm}$ for $5 \mathrm{~min}$ to separate into precipitate and supernatant parts. The precipitate in the serum bottles was recovered by magnetics, washed with distilled water thrice and dried under $\mathrm{N}_{2}$ gas to obtain the biogenic magnetite nanoparticles in the solid phase. For sample preparation for TEM analysis, a 0.1-mL suspension containing magnetite nanoparticles was diluted 100-fold in ethanol and then a drop of the sample was placed on the Cu-grid and dried. XRD analysis was performed using an $X^{\prime}$ Pert PRO (PANalytical, Almelo, The Netherlands) equipped with CuK $\alpha$ radiation (40 kV, $\left.20 \mathrm{~mA}\right)$ at a scan speed of $5 \theta / \mathrm{min}$. The morphology and elemental composition of the synthesized magnetite nanoparticles were determined by HR-TEM analysis using Phillips Tecnai F20 (Philips, Amsterdam, The Netherlands) with an accelerating voltage of $200 \mathrm{kV}$.

\section{Results}

\subsection{Microorganism}

The results of microbial diversity from PCR-DGGE and 16S rRNA gene sequence analysis showed that Haejae-1 consists of Clostridium sp., Enterococcus sp. and Serratia sp. and Haejae-2 subcultured from Haejae-1 consists of Clostridium sp. and unidentified microbes (Figure 1a,b). It is well known that Clostridium sp., a strict anaerobic, gram-positive, spore-forming bacterium common in soils and wastes, is capable of reducing Fe(III), Mn(IV), U(VI) and Pu(IV) via glucose fermentation [19].

The gram-positive cell walls consist mainly of peptidoglycan that is rich in carboxylate groups responsible for the net negative charge of the structure and the formation of minerals [20]. The SEM image showed the rod-shaped bacteria and precipitated magnetite nanoparticles around the cells (Figure 1c). The TEM image of the cell's cross section showed precipitated magnetites surrounding the cell surface (Figure 1d). This indicates that Haejae-2 (mixed culture containing Clostridium sp.) may have contributed to mineral formation extracellularly through biologically-induced biomineralization via glucose fermentation. During the biomineralization process, the release of metabolic wastes (e.g., $\mathrm{O}_{2}, \mathrm{OH}^{-}, \mathrm{HCO}_{3}{ }^{-}, \mathrm{Fe}^{2+}, \mathrm{NH}_{4}{ }^{+}, \mathrm{H}_{2} \mathrm{~S}$ ), enzymatic mediated changes in redox state, or the development of a charged cell surface can all induce the nucleation of amorphous to poorly crystalline minerals [21]. Larson (2009) reported that the Clostridium sp. produced EPS leading to the formation of biofilms and had an extraordinary iron-reductive ability [22]. 

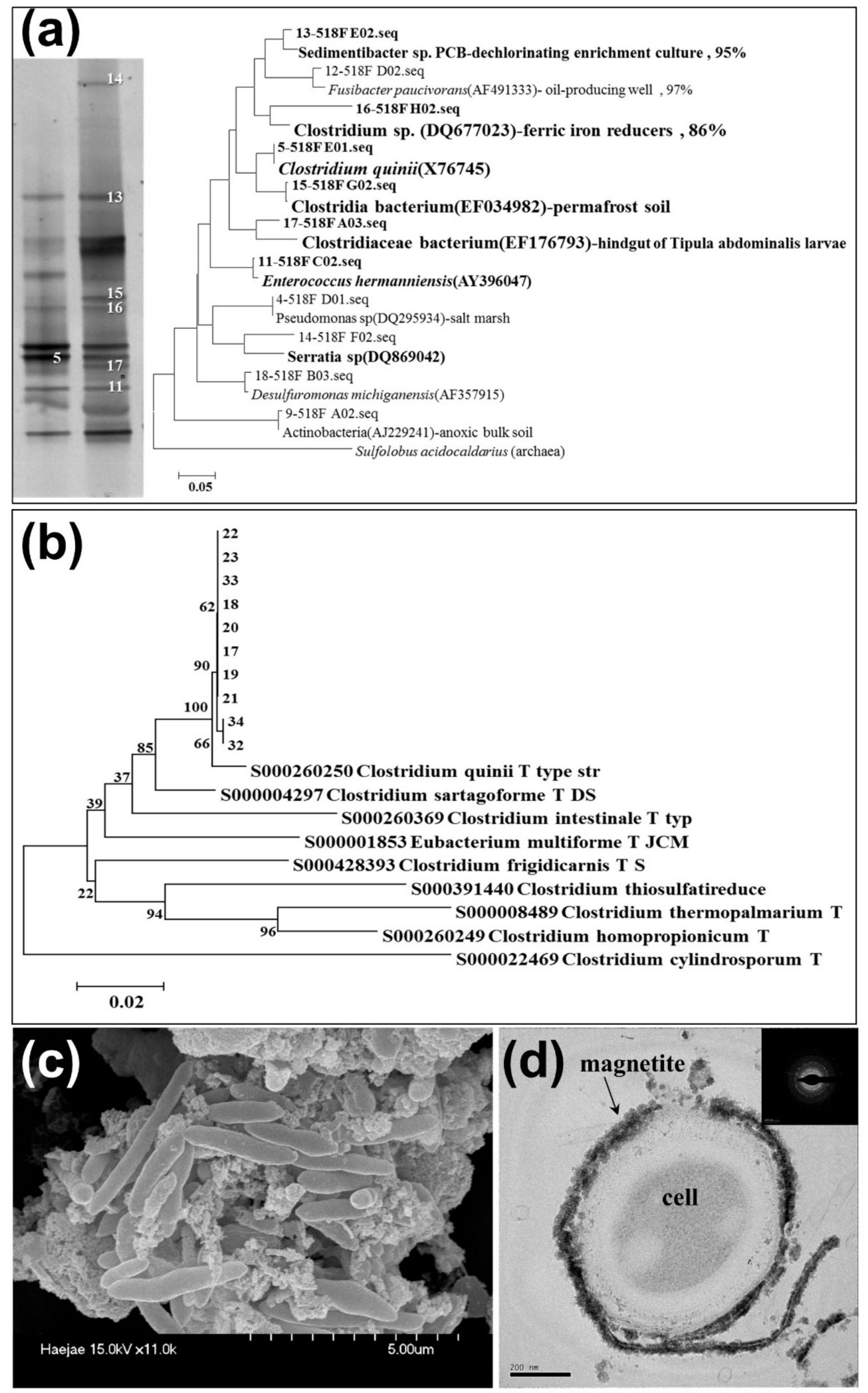

Figure 1. (a) PCR-DGGE band and phylogenetic tree based on 16S rRNA gene analysis of Haejae-1, (b) phylogenetic tree of Haejae-2, (c) scanning electron microscopy (SEM) image of Haejae-2 and (d) transmission electron microcopy (TEM) image and energy dispersive X-ray (EDS) peaks with DP image of cell's cross section showing precipitated magnetites surrounding the cell surface. 


\subsection{The Effect of Incubation Temperature}

To understand the effect of incubation temperature on mineralization, the Haejae-2 were incubated at $8{ }^{\circ} \mathrm{C}, 25^{\circ} \mathrm{C}$, and $35{ }^{\circ} \mathrm{C}$ for 2 weeks. The precipitated particles after the incubation period were collected and mineralogically characterized using TEM-EDS and XRD. Figure 2 showed that magnetite nanoparticles formed at $25^{\circ} \mathrm{C}$ are uniformly sized from 8 to $12 \mathrm{~nm}$, and spherical or hexagonal in shape compared to the sizes of the particles formed at $35^{\circ} \mathrm{C}$ raged from 6 to $25 \mathrm{~nm}$. In previous researches, it has been confirmed that nano-sized magnetite nanoparticles (less than $30 \mathrm{~nm}$ ) formed by microbial processes follow that of typical superparamagnetic behavior [23,24]. However, akaganeite was not transformed to magnetite completely at $8{ }^{\circ} \mathrm{C}$ but mainly formed goethite $(\alpha-\mathrm{FeOOH})$ and few magnetite nanoparticles (Figure 2c). This means that the growth of the bacteria might have been restricted by incubation temperature and, especially, Haejae- 2 synthesized the most regular controlled magnetite nanoparticles at $25^{\circ} \mathrm{C}$ (Figure 2d).

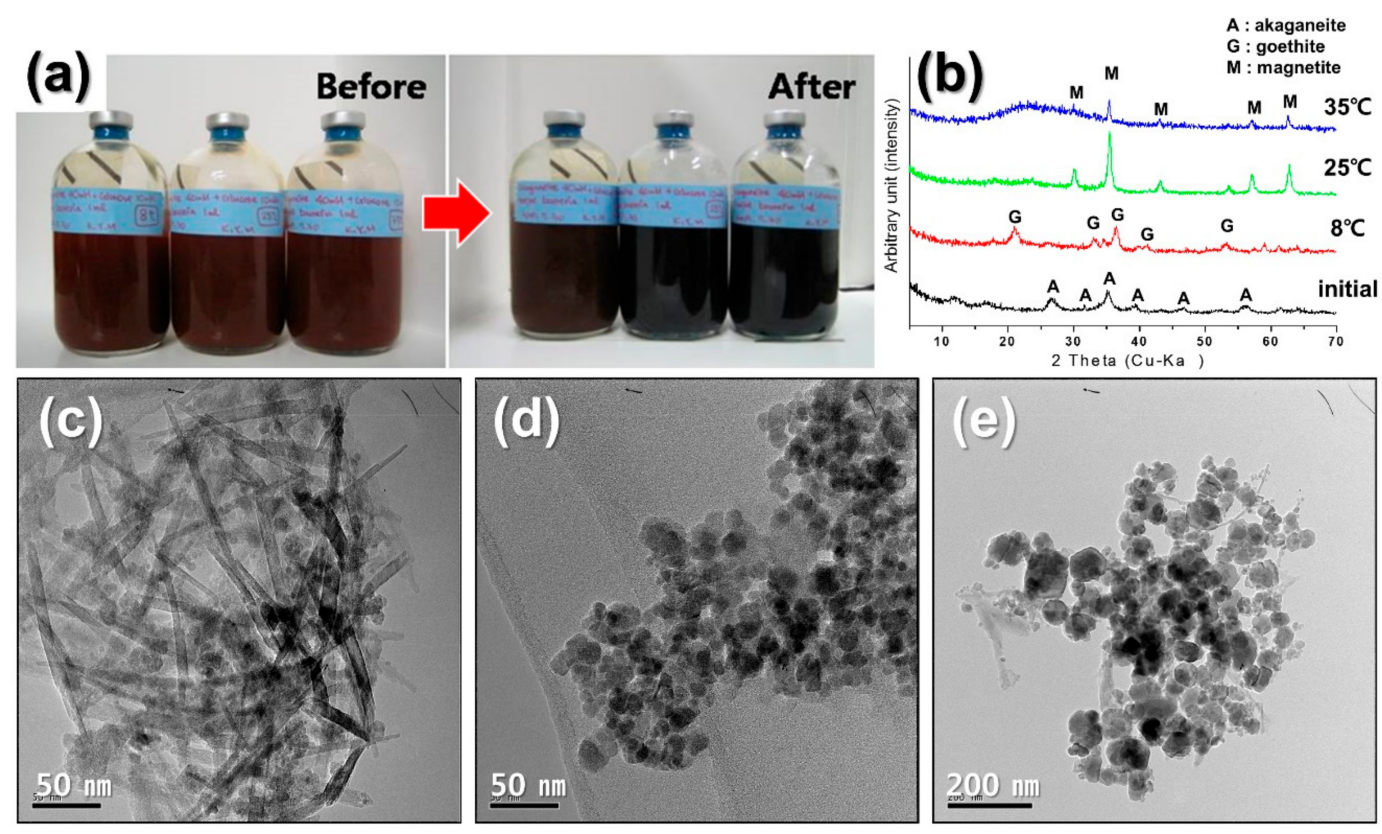

Figure 2. Microbial synthesis of magnetite nanoparticles at different incubation temperatures: (a) Color change followed by the mineral phase transition, (b) X-ray diffraction (XRD) patterns, TEM images of magnetite formed by Haejae-2 at different incubation temperatures at (c) $8{ }^{\circ} \mathrm{C}$, (d) $25^{\circ} \mathrm{C},(\mathbf{e}) 35^{\circ} \mathrm{C}$.

\subsection{The Effect of Concentration of Magnetite Precursor}

The concentration of the magnetite precursor, akaganeite, had an effect on the size of the magnetite nanoparticles (Figure 3). Haejae-2 (mixed culture containing Clostridium sp.) was incubated with various concentrations of akaganeite $(20 \mathrm{mM}, 40 \mathrm{mM}$, and $60 \mathrm{mM})$ for 2 weeks to examine the optimal concentration for the synthesis of nanoparticles of a well-defined size and shape. The microorganisms synthesized magnetite nanoparticles within a week in all conditions (Figure 3), and formed the most uniform size raged from 5 to $10 \mathrm{~nm}$ with a regular shape when using $40 \mathrm{mM}$ akaganeite as a magnetite precursor (Figure 3d). In the $20 \mathrm{mM}$ akaganeite, a small amount of magnetite nanoparticles was formed 2 to $7 \mathrm{~nm}$ in size (Figure 3c). While the irregularity in size increased in the high concentration of $60 \mathrm{mM}$ of magnetite precursor ranged from 8 to $20 \mathrm{~nm}$, shapes of magnetite nanoparticles appeared to have no differences (Figure 3e). These results indicate that magnetite crystals grow larger with increased concentrations of iron oxyhydroxide since the magnetite precursor plays a role in the nucleation of crystalline magnetite nanoparticles. 

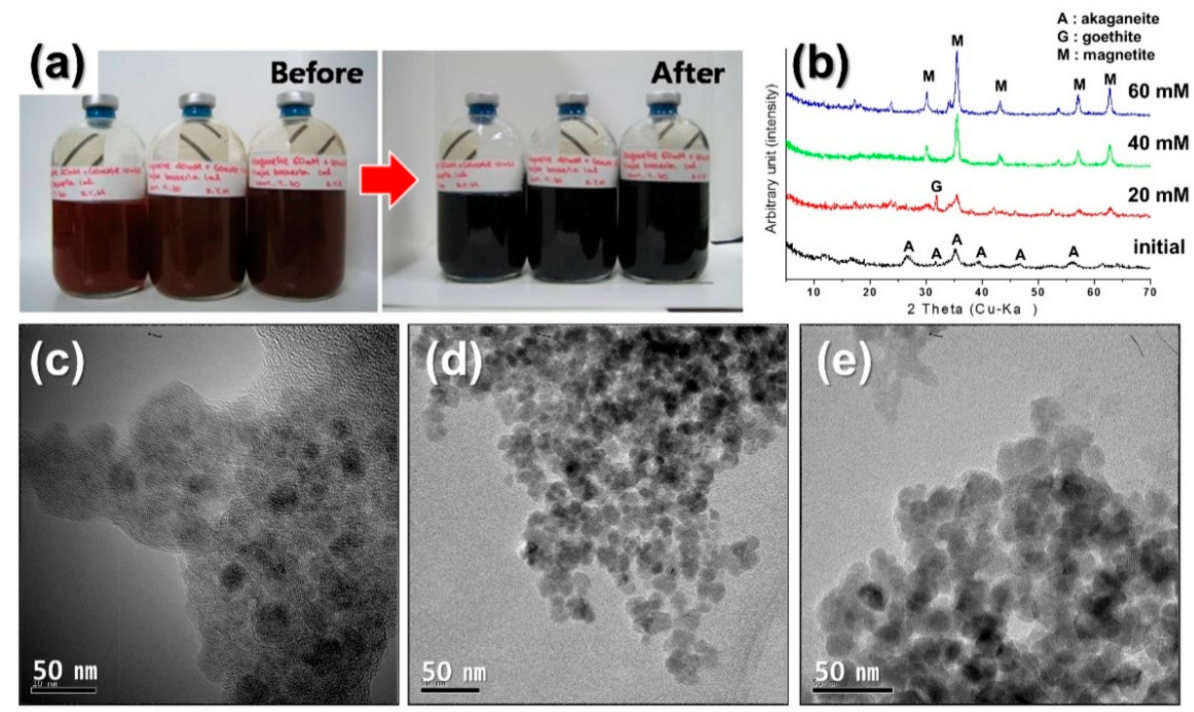

Figure 3. Microbial synthesis of magnetite nanoparticles at different concentrations of magnetite precursors: (a) Color changes by the mineral phase transition, (b) XRD patterns, TEM images of magnetite formed by Haejae-2 with different concentrations of akaganeite [(c) $20 \mathrm{mM}$, (d) $40 \mathrm{mM}$,

(e) $60 \mathrm{mM}$.

\subsection{The Effect of Medium $p H$}

Haejae-2 produced magnetite nanoparticles extracellularly at all $\mathrm{pH}$ levels with the nanoparticles having a predominantly spherical shape (Figure 4). However, the tendency was that the higher the $\mathrm{pH}$ value, the faster reduction rate that was exhibited; for instance, changes in color appeared from brown to black in $\mathrm{pH}=8.5$ within $24 \mathrm{~h}$ followed by $\mathrm{pH}=7.5$ within $48 \mathrm{~h}$ and $\mathrm{pH}=6.5 \mathrm{ca} .50 \mathrm{~h}$.

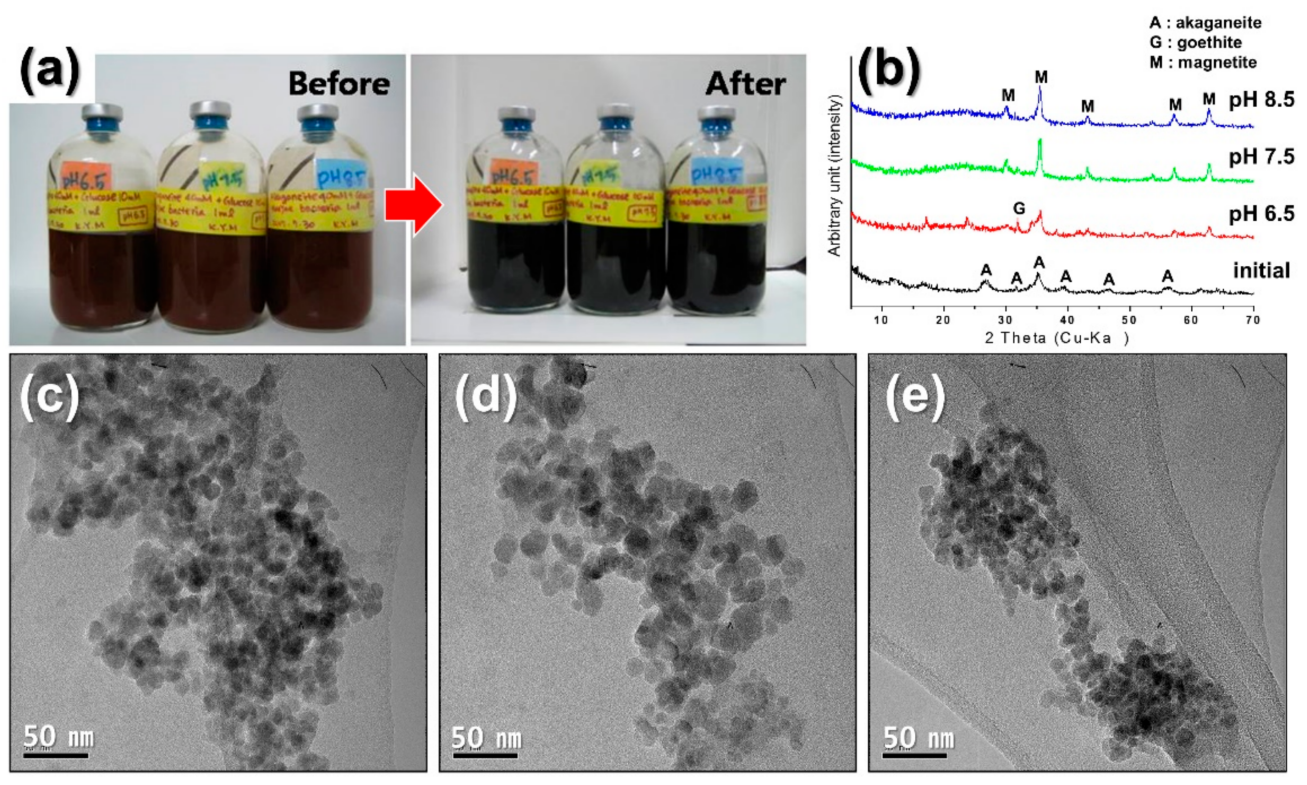

Figure 4. Microbial synthesis of magnetite nanoparticles at different $\mathrm{pHs}$ of medium: (a) Color changes by the mineral phase transition, (b) XRD patterns, TEM images of magnetite formed by Haejae-2 at different $\mathrm{pH}$ values of media at (c) $\mathrm{pH}=6.5$, (d) $\mathrm{pH}=7.5$, (e) $\mathrm{pH}=8.5$.

The most rapid color change from brown to black occurred in the medium of $\mathrm{pH}=8.5$. The black precipitates were identified as magnetite $5 \sim 10 \mathrm{~nm}$ in size (Figure $4 \mathrm{~b}, \mathrm{e}$ ). Magnetites formed in the 
medium with a $\mathrm{pH}=7.5$ were $5 \sim 25 \mathrm{~nm}$ larger in size (Figure $4 \mathrm{~d}$ ), while magnetite nanoparticles formed in a medium with a $\mathrm{pH}=6.5$ were approximately $15 \mathrm{~nm}$ in size (Figure $4 \mathrm{c}$ ). Thus, the growth rate of Haejae-2 directly reflected the formation rate of magnetite nanoparticles at $\mathrm{pH}$ levels between 6.5 and 8.5. Furthermore, the optimal condition for magnetite that was the smallest in size and the most homogeneous in shape was with $\mathrm{pH}=8.5$.

\subsection{The Effect of Incubation Time}

Haejae-2 was incubated with $40 \mathrm{mM}$ akaganeite and $10 \mathrm{mM}$ glucose in the growth medium at room temperature. The nanoparticles produced using the bacteria were then harvested for TEM and XRD analyses after 24-h, 48-h, 1-week, and 2-week incubation. The particles were observed to have transformed from akaganeite to magnetite within 24-h of incubation (Figure 5a,b). Magnetite particles of less than $5 \mathrm{~nm}$ in size co-existed with iron oxyhydroxide such as akaganeite and goethite after 24-h (Figure 5b). The TEM images taken after $48 \mathrm{~h}$ showed a copious amount of magnetite nanoparticles (Figure 5c). By the first week, most of the iron oxyhydroxide disappeared, and ca. $10 \mathrm{~nm}$ spherical-shaped magnetite particles were observed in great abundance (Figure 5d). The grain sizes of the magnetite particles increased with incubation times, which may have resulted from crystal nucleation and growth [13]. Therefore, Haejae-2 (mixed culture containing Clostridium sp.) needed at least one week to completely synthesize magnetite with $40 \mathrm{mM}$ akaganeite and $10 \mathrm{mM}$ glucose under an anoxic condition at room temperature.
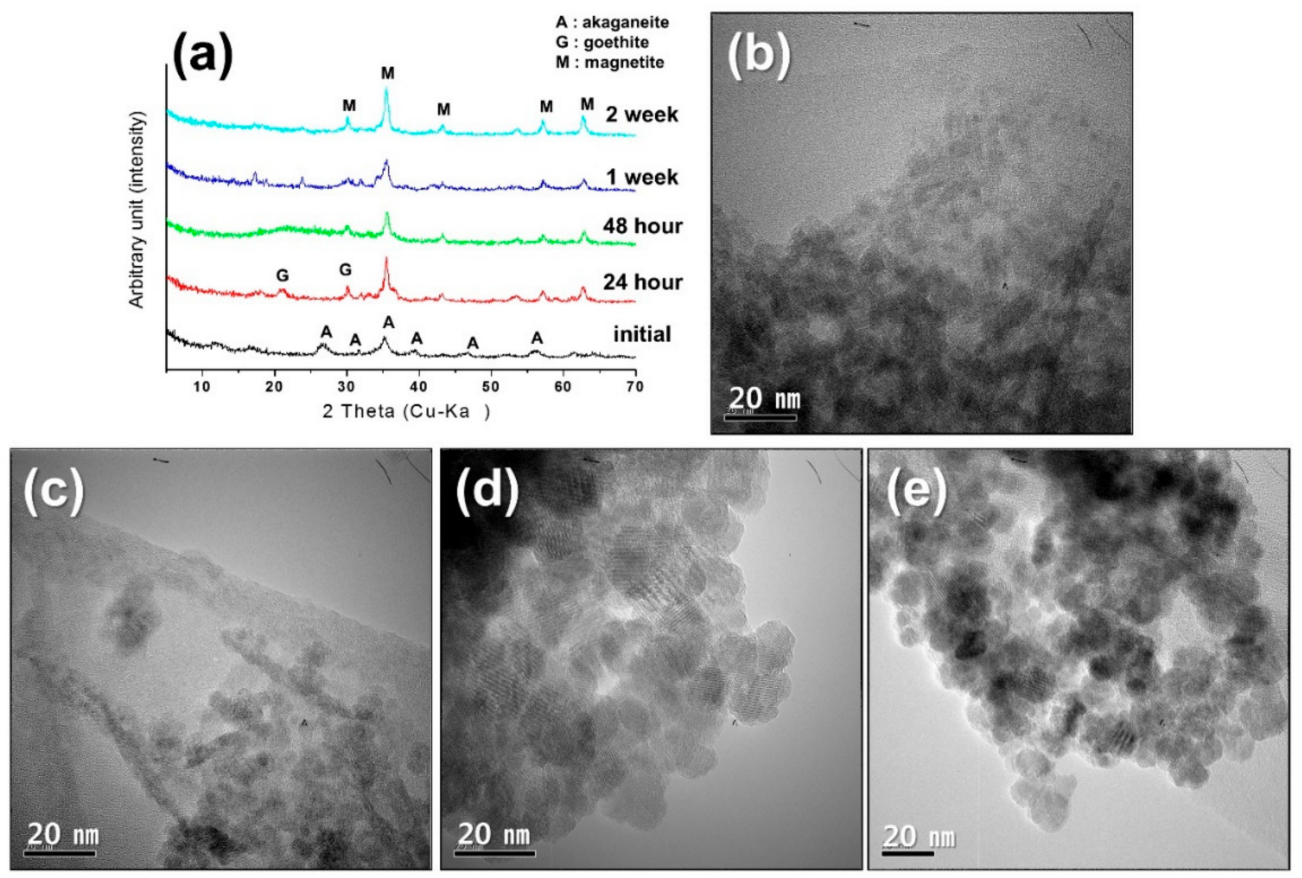

Figure 5. Microbial synthesis of magnetite nanoparticles at different incubation time: (a) XRD patterns, TEM images of magnetite formed by Haejae-2 at different incubation time [(b) 24-h, (c) 48-h, (d) 1-week, (e) 2-week].

\section{Conclusions}

The Fe(III)-reducing bacteria enriched from the inter-tidal flat sediments, Haejae-2, consist of Clostridium and unidentified species. Haejae-2 formed $2 \sim 10 \mathrm{~nm}$-sized magnetite $\left(\mathrm{Fe}_{3} \mathrm{O}_{4}\right)$ especially by the reduction of $40 \mathrm{mM}$ akaganeite under the conditions of $25^{\circ} \mathrm{C}$ and medium $\mathrm{pH}=8.5$ within a week incubation period. These results demonstrate that the rate of formation and the morphology of microbially synthesized nanoparticles could be manipulated by controlling the microbial growth conditions such as temperature, concentration of mineral precursor, the medium $\mathrm{pH}$, and the incubation 
time. The magnetite nanoparticles formed by the microbial processes exhibit superparamagnetic behavior and can be useful for relevant medical and physical applications. Compared with Geobacter and Shewanella species, which are well known as Fe(III)-reducing bacteria, the Haejae-2 (mixed culture containing Clostridium sp.) is ubiquitous in natural environments and is relatively easy to cultivate. Therefore, there is a high possibility of various industrial applications in terms of mass production of magnetite with cost-efficiency using microorganisms.

Author Contributions: Y.K. designed the experiments, performed analysis on all samples, interpreted data, wrote manuscript; Y.R. conceived the original idea, provided critical feedback, acted as corresponding author.

Acknowledgments: This research was supported by the "Basic Science Research Program" of the National Research Foundation of Korea funded by the Ministry of Education (NRF-2015R1D1A4A01016016 and NRF-2016R1D1A1A09917588). We are grateful to Moon at KBSI-Gwangju Branch for SEM/TEM-EDS analyses, and Jung at CCRF in Chonnam National University for XRD analysis.

Conflicts of Interest: The authors declare no conflict of interest.

\section{References}

1. Coker, V.S.; Pattrick, R.A.D.; Laan, G.V.D.; Lloyd, J.R. Formation of magnetic minerals by non-magnetotactic prokaryotes. Microbiol. Monogr. 2006, 3, 276-295.

2. Mohanpuria, P.; Rana, N.K.; Yadav, S.K. Biosynthesis of nanoparticles: Technological concepts and future applications. J. Nanopart. Res. 2008, 10, 507-517. [CrossRef]

3. Lovley, D.R. Microbial Fe(III) reduction in subsurface environments. FEMS Microbiol. Rev. 1997, 20, 305-313. [CrossRef]

4. Bhattacharya, D.; Rajinder, G. Nanotechnology and potential of microorganisms. Crit. Rev. Biotechnol. 2005, 25, 199-204. [CrossRef] [PubMed]

5. Gericke, M.; Pinches, A. Biological synthesis of metal nanoparticles. Hyderometallurgy 2006, 83, 132-140. [CrossRef]

6. Gericke, M.; Pinches, A. Microbial production of gold nanoparticles. Gold Bull. 2006, 39, 22-28. [CrossRef]

7. Berger, P.; Adelman, N.B.; Beckman, K.J.; Campbell, D.J.; Ellis, A.B.; Lisensky, G.C. Preparation and properties of an aqueous ferrofluid. J. Chem. Educ. 1999, 76, 943-948. [CrossRef]

8. Kim, D.K.; Zhang, Y.; Voit, W.; Rao, K.V.; Muhammed, M. Synthesis and characterization of surfactant-coated superparamagnetic monodispersed iron oxide nanoparticles. J. Magn. Magn. Mater. 2001, 225, 30-36. [CrossRef]

9. Shinkai, M. Functional magnetic particles for medical application. J. Biosci. Bioeng. 2002, 94, 606-613. [CrossRef]

10. Love, L.J.; Jansen, J.F.; McKnight, T.E.; Roh, Y.; Phelps, T.J.; Yeary, L.W.; Cunningham, G.T. Ferrofluid field induced flow for microfluidic applications. IEEE/ASME Trans. Mechatron. 2005, 10, 68-76. [CrossRef]

11. Zhang, L.Y.; Gu, H.C.; Wang, X.M. Magnetite ferrofluid with high specific absorption rate for application in hyperthermia. J. Magn. Magn. Mater. 2007, 311, 228-233. [CrossRef]

12. Zhang, C.; Vali, H.; Romanek, C.S.; Phelps, T.J.; Liu, S.V. Formation of single-domain magnetite by a thermophilic bacterium. Am. Mineral. 1998, 83, 1409-1418. [CrossRef]

13. Roh, Y.; Park, B.; Lee, J.; Oh, J.; Lee, S.; Han, J.; Kim, Y.; Seo, H. Mineralogy and biogeochemistry of intertidal flat sediment, Muan, Chonnam, Korea. J. Mineral. Soc. Korea 2007, 20, 47-60.

14. Sun, E.; Kim, Y.; Park, B.; Roh, Y. Environmental Application of Nanomaterials and Metal-Reducing Bacteria to Remediate Arsenic-Contaminated Groundwater. J. Nanosci. Nanotechnol. 2011, 11, 1589-1592. [CrossRef] [PubMed]

15. Kim, Y.; Jang, H.; Suh, Y.; Roh, Y. Characterization of magnetite-organic complex nanoparticles by metal-reducing bacteria. J. Nanosci. Nanotechnol. 2011, 11, 7242-7245. [CrossRef] [PubMed]

16. Kim, S.J.; Park, S.J.; Yoon, D.N.; Park, B.J.; Choi, B.R.; Lee, D.H.; Roh, Y.; Rhee, S.K. Marinobacterium maritimum sp. nov., a marine bacterium isolated from Arctic sediment. Int. J. Syst. Evol. Microbiol. 2009, 59, 3030-3034. [CrossRef] [PubMed]

17. Roh, Y.; Vali, H.; Phelps, T.J.; Moon, J.W. Extracellular synthesis of magnetite and metal-substituted magnetite nanoparticles. J. Nanosci. Nanotechnol. 2006, 6, 3517-3520. [CrossRef] [PubMed] 
18. Roh, Y.; Lauf, R.J.; McMillanm, A.D.; Zhang, C.; Rawn, C.J.; Bai, J.; Phelps, T.J. Microbial synthesis and the characterization of metal substituted magnetites. Solid State Commun. 2001, 118, 529-534. [CrossRef]

19. Francis, A.J.; Dodge, C.J.; Gillow, J.B. Reductive dissolution of $\mathrm{Pu}(\mathrm{IV})$ by Clostridium sp. under anaerobic conditions. Environ. Sci. Technol. 2008, 42, 2355-2360. [CrossRef] [PubMed]

20. Frankel, R.B.; Bazylinski, D.A. Biologically induced mineralization by bacteria. Rev. Mineral. Geochem. 2003, 54, 95-114. [CrossRef]

21. Konhauser, K. Introduction to Geomicrobiology; Blackwell Science Ltd.: Oxford, UK, 2007; p. 425, ISBN-13 978-0632054541.

22. Larson, B.A. X-ray Spectromicroscopy Analysis and Its Applications to Bacterial Interactions in the Environment. Ph.D. Thesis, Stony Brook University, New York, NY, USA, 2009.

23. Yang, T.Z.; Shen, C.M.; Li, H.; Zhang, H.R.; Xiao, C.W.; Chen, S.T.; Xu, Z.C.; Shi, D.X.; Li, J.Q.; Gao, H.J. Highly ordered self-assembly with large area of $\mathrm{Fe}_{3} \mathrm{O}_{4}$ nanoparticles and the magnetic properties. J. Phys. Chem. B 2005, 109, 23233-23236. [CrossRef] [PubMed]

24. Kim, Y.; Roh, Y. Microbial synthesis and characterization of superparamagnetic Zn-substituted magnetite nanoparticles. J. Nanosci. Nanotechnol. 2015, 15, 6129-6132. [CrossRef] [PubMed]

(C) 2018 by the authors. Licensee MDPI, Basel, Switzerland. This article is an open access article distributed under the terms and conditions of the Creative Commons Attribution (CC BY) license (http:/ / creativecommons.org/licenses/by/4.0/). 